ISSN 0122-5383

\title{
POLYMER GELS \\ FOR CONTROLLING WATER THIEF ZONES IN INJECTION WELLS
}

\author{
GELES POLIMÉRICOS PARA EL CONTROL DE ZONAS \\ LADRONAS DE AGUA EN POZOS INYECTORES
}

Gustavo-Adolfo Maya-Toro ${ }^{1 *}$, Rubén-Hernán Castro-García², Zarith del Pilar Pachón-Contreras ${ }^{1}$ and José-Francisco Zapata-Arango ${ }^{2}$

1 Ecopetrol S.A. - Instituto Colombiano del Petróleo (ICP), A.A. 4185 Bucaramanga, Santander, Colombia 2 Ecopetrol S.A. - Superintendencia de Yacimientos, Bogotá, Cundinamarca, Colombia

e-mail: gustavo.maya@ecopetrol.com.co

(Received Mar. 07, 2012; Accepted Oct. 19, 2012)

\section{ABSTRACT}

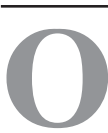

il recovery by water injection is the most extended technology in the world for additional recovery, however, formation heterogeneity can turn it into highly inefficient and expensive by channeling injected water. This work presents a chemical option that allows controlling the channeling of important amounts of injection water in specific layers, or portions of layers, which is the main explanation for low efficiency in many secondary oil recovery processes. The core of the stages presented here is using partially hydrolyzed polyacrylamide (HPAM) cross linked with a metallic ion $\left(\mathrm{Cr}^{+3}\right)$, which, at high concentrations in the injection water (5000 - 20000 ppm), generates a rigid gel in the reservoir that forces the injected water to enter into the formation through upswept zones.

The use of the stages presented here is a process that involves from experimental evaluation for the specific reservoir to the field monitoring, and going through a strict control during the well intervention, being this last step an innovation for this kind of treatments. This paper presents field cases that show positive results, besides the details of design, application and monitoring.

Keywords: Water injection, Bulk gels, Water channeling, Enhanced oil recovery, Conformance.

How to cite: Maya-Toro, G. A., Castro-García, R. H., Pachón-Contreras, Z. \& Zapata-Arango, J. F. (2012). Polymer gels for controlling water thief zones in injection wells. CT\&F - Ciencia, Tecnología y Futuro, 5(1), 37-44.

*To whom correspondence should be addressed 


\section{RESUMEN}

I recobro de hidrocarburos mediante inyección de agua es la tecnología de recobro adicional más extendida en el mundo, sin embargo, la heterogeneidad del yacimiento puede convertirlo en altamente ineficiente o costoso al provocar la canalización del agua. Este trabajo presenta una opción química que, al ser implementada, permite controlar la canalización de altos porcentajes de agua inyectada en arenas, o fracciones de arenas específicas; lo cual es una de las principales explicaciones para la baja eficiencia de muchos procesos de recobro secundario. El corazón de los pasos o etapas aquí discutidos es la mezcla de agua con poliacrilamida parcialmente hidrolizada (HPAM), a concentraciones entre 5000 y 20000 ppm, y un ion metálico $\left(\mathrm{Cr}^{+3}\right)$, mezcla que en el yacimiento forma un gel rígido que desvía el agua inyectada hacia zonas no barridas.

Las etapas mencionadas incluyen desde evaluación experimental hasta monitoreo en campo, pasando por un control estricto de la operación en el pozo inyector, siendo este último componente completamente innovador para este tipo de tratamientos. Se presentan aquí resultados de campo que demuestran beneficios, al tiempo que se detalla el proceso de diseño, aplicación y seguimiento.

Palabras claves: Inyección de agua, Geles rígidos, Canalización de agua, Recobro mejorado.

\section{RESUMO}

recobro de hidrocarbonatos mediante injeção de água é a tecnologia de recobro adicional mais
estendida no mundo, entretanto, a heterogeneidade da jazida pode convertê-lo em altamente
ineficiente ou caro. Este trabalho apresenta uma opção química que, ao serem implementados,
permitem controlar a canalização de altas porcentagens de água injetada em areias, ou frações de areias,
específicas; o qual é uma das principais explicações para a baixa eficiência de muitos processos de reco-
bro secundário. O coração dos passos ou etapas aqui discutidos á a mistura de água com poliacrilamida
parcialmente hidrolisada (HPAM), a concentrações entre 5000 y 20000 ppm, e um ín metálico $\left(\mathrm{Cr}^{+3}\right)$;
mistura que no jazida forma um gel rígido que desvia a água injetada a zonas não barridas.
As etapas mencionadas incluam desde avaliação experimental até monitoramento em campo, passando por
um controle estrito da operação do poço tratado, sendo este último componente completamente inovador
para este tipo de tratamentos. Apresentam aqui resultados de campo que demonstram benefícios, ao tempo
que se detalha o processo de desenho, aplicação e seguimento.

Palavras chaves: Injeção de água, Géis rígidos, Canalização de água, Recobro melhorado. 


\section{INTRODUCTION}

Injecting water into oil production sands is one of the most employed options to increase the recovery factor that may be obtained from them. Water injection is used to displace the oil from the reservoir or to apply pressure to the reservoir; it is adversely affected when the heterogeneities of the formation do not allow for an efficient sweeping of oil with the use of the water. An important variation in the petrophysical properties of the formation, reflected in a greater or lesser ability to allow the flow of fluids, will make the injected water move preferentially through specific areas from injection wells to production wells, resulting in early irruption of the water. Since the injected water will always take the easiest hydraulic path, once the previous stage has occurred, the water will begin to flow preferentially through the flooded area, drastically decreasing sweep efficiency in remaining areas, resulting in an inefficient process. Developing knowledge that allows us avoid the loss of efficiency, described in the previous paragraph, is a current need and essential improvement in relation to the optimal implementation of secondary recovery processes.

The basic technology for this study was presented initially by Gall (1973), who was one of the precursors of the chemical conformance that is, those methods which seek to obtain an improvement in volumetric efficiency of the water injection inside the reservoir, through chemicals compounds that will force the injected water to take new paths that have not yet been swept.

The chemical conformance technique considered here is based on the use of partially hydrolyzed polyacrylamide, cross-linked with a metal ion. This mixture, under previously studied conditions, generates rigid gels in the inside of the reservoir.

This paper presents a methodology developed by the authors, conceived aiming to design and implement a systematic process of chemical conformance with polymer gels, beginning with the design stage and covering up to the implementation phase as well as QA / QC (Quality Analysis / Quality Control), which until now was not a rigorous part of the application of these processes. The work presented here includes an application example, where positive results obtained by applying the methodology designed may be observed.

\section{THEORETICAL BACKGROUND AND TECHNIQUE STATE}

The patent office of the United States granted to James W. Gall (1973) the first patent that proposes the use of chemical substances in water injection wells, in order to correct the water permeability of the formation. The proposal to apply technology consisted of injecting HPAM first at a given concentration, followed by a cross-linker $\left(\mathrm{Cr}^{+3}\right)$, expecting both react at the reservoir to form a polymer gel to divert the water injected into new areas.

The patent described above was followed by others (Gall, 1976-1977) wherein the scientific basis was of the same technology as that of polymeric gels. However, the processing carried out as described by them showed unsatisfactory results (Sydansk \& Argabright, 1987) due to the inability to obtain a complete mixture of the components in the formation.

During the 80s the Marathon Oil Company marked a significant change in the polymer gel technology used to date, by taking the base of the same chemical formula and modifying the manner in which it was applied (Sydansk \& Argabright, 1987). The HPAM and metal ion (cross linker) are contacted from the surface, ensuring their mixture and increasing the reaction time.

The commercial success of this technology started between 1984 and 1987, when Marathon Oil Company executed 29 treatments, for a total of 3.7 millions incremental barrels at only $\$ 0.34$ for each of them (Borling, Chan, Hughes \& Sydansk, 1994). It was also at this time when the difference between the concepts of Water ShutOff (WSO) and conformance was established, relating the first term to the simple isolation of thief zones while the second refers to the intervention in terms of permeability within the formation from the injection wells.

The chemical and physical concepts underlying the application of polymer gels as a tool for conformance in injection wells have been the subject of little research, beyond the work of Sydansk and Argabright (1987), mainly because efforts are focused in blocking water producing areas (producing wells - WSO).

Two of the most important works were carried out by Klaveness and Ruoff (1994) and by Klave- 


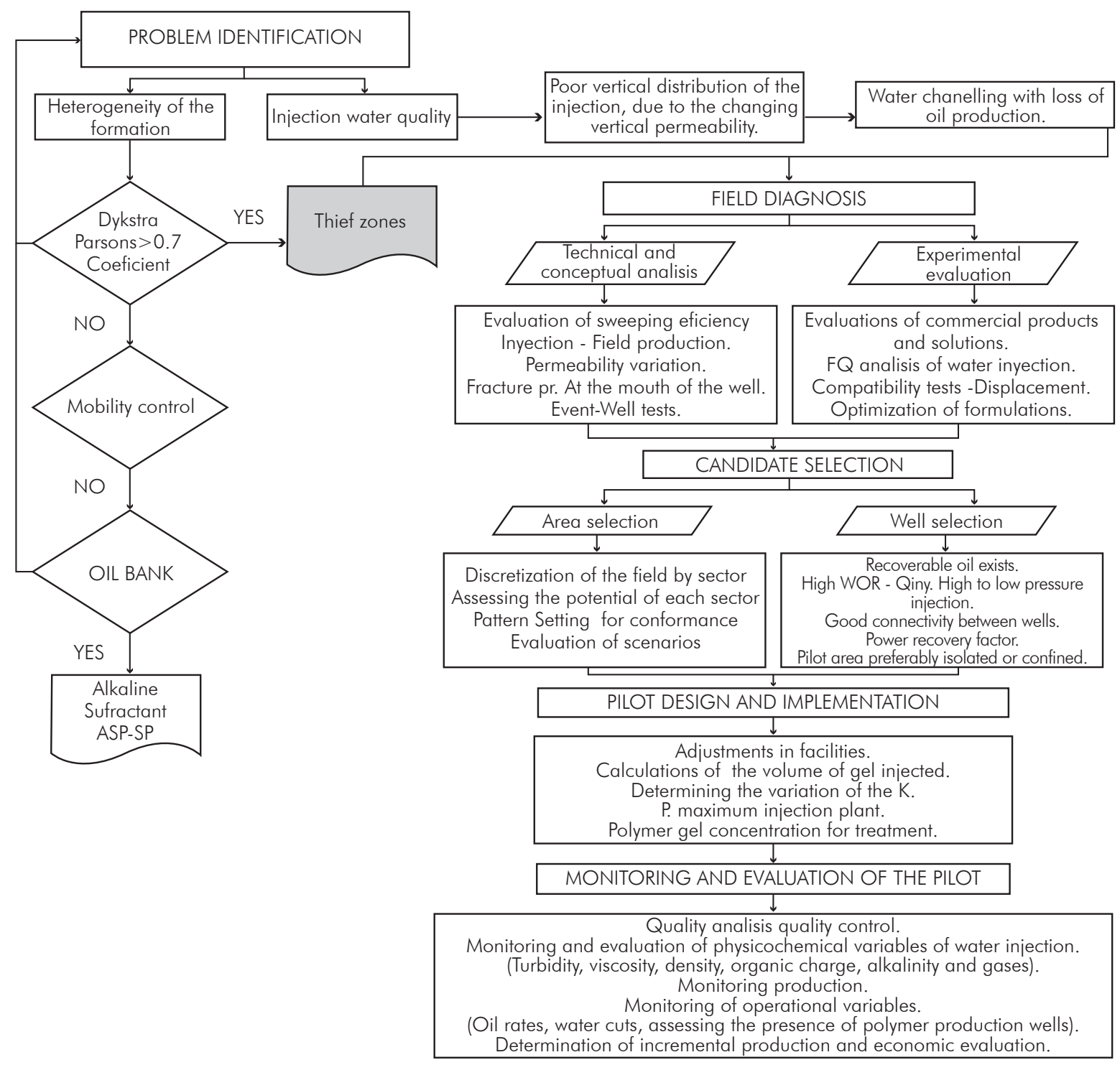

Figure 1. Methodology for the control of water thief zones in injection wells.

ness, Ruoff and Kolnes (1995). The main theme in both investigations is the kinetics of the reaction of HPAM with $\mathrm{Cr}^{+3}$ from rheological measurements and ultraviolet radiation. However, both papers are kept at laboratory scale and exclude the rock component, and in this manner, the main questions remain unanswered. Despite not having sufficient phenomenological explanations for the process, both in the surface area and reservoir, this has become common practice since its commercial success.

In 2010, the American Society of Petroleum Engineers (SPE) published a book titled Reservoir Conformance Improvement (Sydansk \& Romero-Zerón,
2011), where the practical aspect of the process is given more importance than the theoretical elements of the topic, and wherein the polymer gels are considered as a viable option within a general framework of technologies that can be used to tackle problems regarding conformance, however, it does not make an in depth study on the concepts and questions that remain un resolved in relation to the application of polymer gels.

The current state of the technology allows identifying positive outcomes on projects undergone in different parts of the world, including countries like Argentina (Wouterlood, Falcigno \& Norman, 2002) and Venezuela (Norman et al., 2006). 

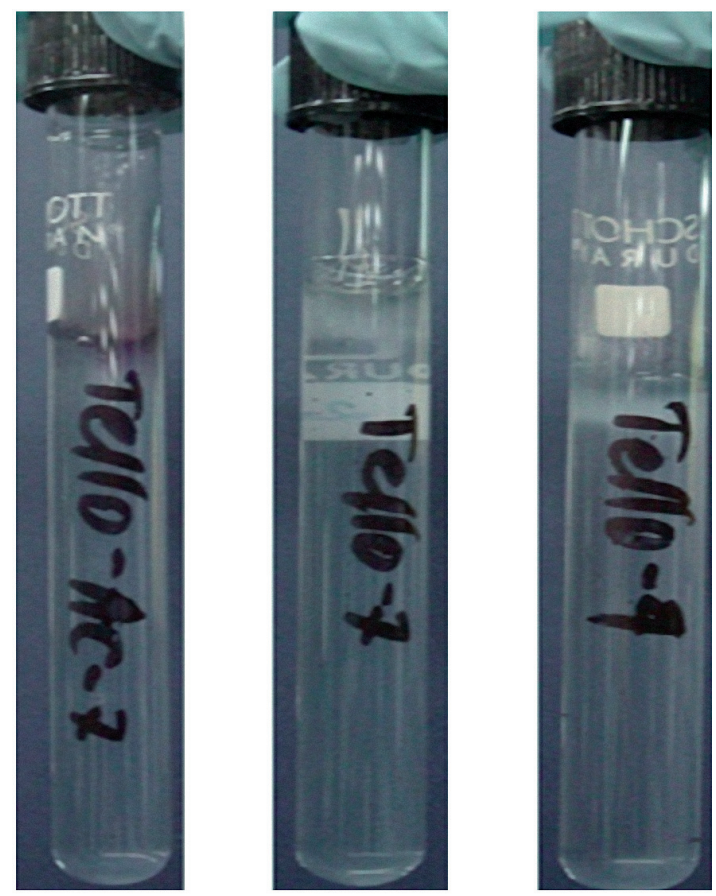

Figure 2. Different mixtures of polymer gels for study (protocol developed by Marathon Oil Company).

\section{EXPERIMENTAL DEVELOPMENT}

The methodology developed, to control thief zones in water injection processes, is presented in Figure 1, in which details are given ranging from the problem identification stage to the monitoring and evaluation regarding the implementation of a pilot project. The main steps required by the methodology are: problem identification, field diagnostics, candidate selection, design and pilot implementation and monitoring and evaluation of the pilot. To this date, these steps were not performed in an integrated manner, or with the detail offered in this research paper.

\section{Problem Identification}

The problem at identification stage aims to determine whether there are areas where the injected water is flowing in a preferential manner. This stage focuses on an injection / production analysis, as well as a detailed review of injection tests ((ILT) Injection Logging Tools) and the events of the wells. Results such as the coefficient of Dykstra - Parsons, an account of the interconnected zones of the field and maps such like water cut maps or oil produced maps are basic at this stage (Delgadillo, 2010), identifying the areas of the field where water production is bigger than expected and therefore the process is not as efficient as it could be.

This first step includes a first approach to the quality of injection water as well as to the possible incompatibilities with production water. To achieve this, samples of injected water are analyzed in the wellhead or in candidate wells that could be in operation in the near future.

\section{Field Diagnostics}

Once the previous step is taken care of, the diagnosis of the producing sands must now be carried out. This is accomplished with the same type of analysis, but decreasing the scale, focusing attention on those areas where the problem identified in the preceding stage is greater. Afterwards, proceed to undergo a field zonification according to the results shown in the previous stage.

It is important to note that a precise diagnostic of channeling between wells may be done by the use of chemical tracer; however, this type of information is not always available.

At this point, the experimental phase is also taken to another level. Sampling and physico-chemical analyzes performed in the previous section are used to run the test protocols on formation of polymer gels.

Figure 2 shows one example of the tests to be performed in the laboratory. These tests are founded on the technology of polymer gels initially designed by the Marathon Oil Company, and is based on mixing, using injection water, polymer at different concentrations $(500-1000-1500-2000-8000 \mathrm{ppm})$ with the metal ion in different ratios $(20: 1-40: 1-60: 1-80: 1)$, which are considered the most efficient in commercial applications. The mixtures are taken to reservoir temperature (reservoir under study) and visual results are observed during one month.

The behavior, during a lapse of time, of the mixtures gives way to the identification of the degree of rigidity, in qualitative form, obtained by the polymer gel in each of them. The characteristics of the mixtures (gel concentration, metal ion concentration, etc.) that present the best results (high rigidity) are chosen as those that must be incorporated in the mixture which ultimately will be brought to field. 


\section{Candidate Selection}

For the selection of candidate wells, the scale of study is reduced once again in order to analyze every injection well with each possible influenced production well, both from the first and the second line (Ibarra, 2010). The main curves analyzed are water oil relation (WOR) $v s$. cumulative oil produced $\left(\mathrm{N}_{\mathrm{p}}\right)$; produced water $\left(\mathrm{Q}_{\mathrm{i}}\right)$ vs. $\mathrm{N}_{\mathrm{p}}$; produced oil $\left(\mathrm{Q}_{\mathrm{o}}\right) v s$. $\mathrm{N}_{\mathrm{p}}$; total produced fluids $\left(\mathrm{Q}_{\mathrm{T}}\right)$ vs. $\mathrm{N}_{\mathrm{p}}$; each one of them being different ways, or criteria for observing the behavior of the fluid production in relation to water injection. Figure 3 shows an example of this type of graphic, allowing to accurately determining the presence of channels and providing channel size data present between the (injector / producer) analyzed wells.

The curves in Figures $3 a$ and $3 b$ are particularly important in the selection of the injector wells where a

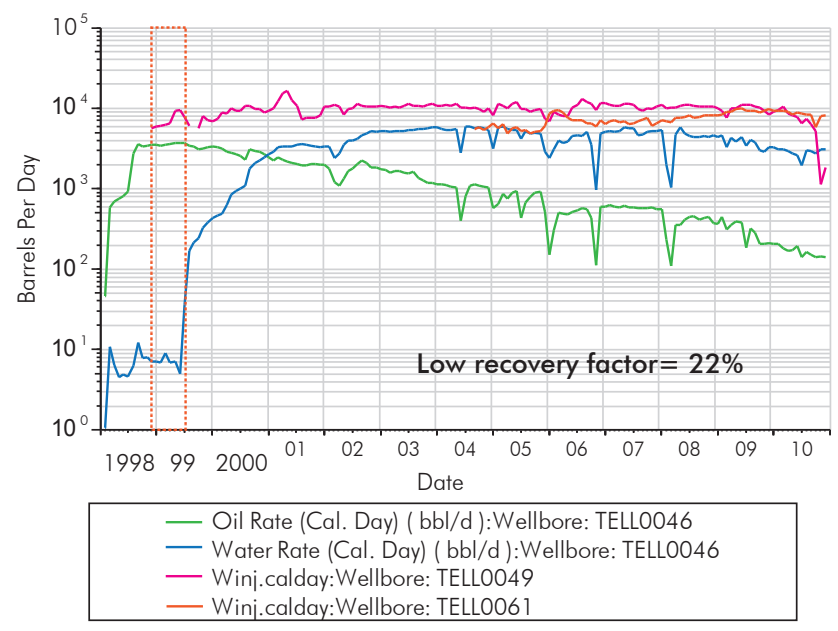

(a)

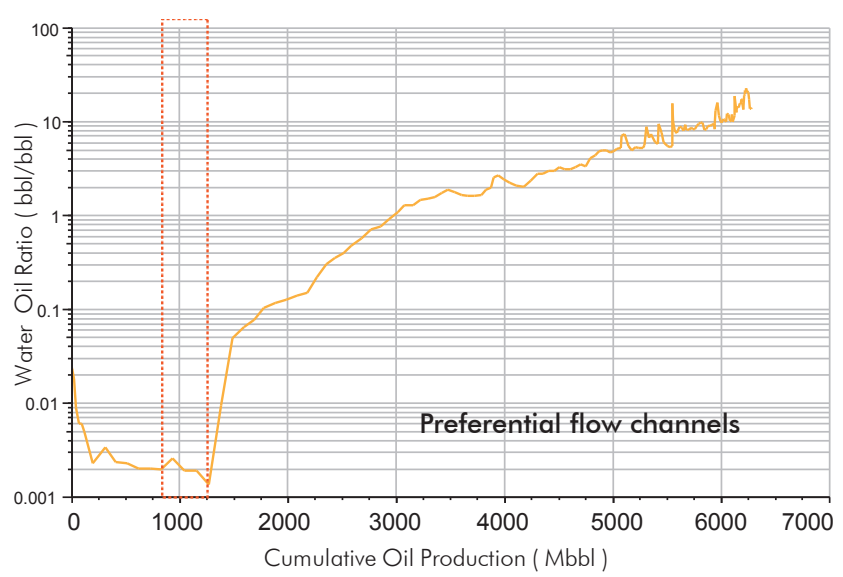

(b)

Figure 3. Graphic analysis of two wells under study (injector / production) (a) Rate vs. date, (b) WOR vs. Np. polymeric gel treatment for water channeling control should be applied. A sudden increase in the value of the WOR evidences that injected water is reaching the producer wells very quickly. Analyzing this curve together with the oil and water production rates, it is possible to establish the volume of the channel like the volume between the moment where WOR begin to decrease and where it rise strongly.

\section{Design and Implementation of the Pilot}

By combining the steps mentioned above we now have a volume design and specifications of the gel that will be injected. The diagnostic step provides chemical specifications, polymer concentration and polymer metal ion ratio needed and, the selection of candidates carried out also provides the channel volume that must be blocked.

The total volume of the channel identified cannot usually be injected, since it would not be an economically viable method. For this reason, a percentage of volume is defined as the batch size to be injected. The selected percentage normally varies between 5 and $25 \%$ of the channel volume.

At this point the operational conditions that may arise during injection in the field must be analyzed; pressure representing the variable of greater importance. The maximum pressure that can be achieved is determined both by the maximum injection pressure and the fracture pressure of the formation. As a general rule it is suitable to have a margin of pressure below the fracture pressure close to $200 \mathrm{psi}$, so that one can count on a margin of operational leeway.

Field facilities are the next factor to be considered, there must be availability of enough pumping capacity to handle the injection pressure and the volume to be injected, as well as enough surface space for proper equipment localization.

The key factors for the success of the pilot are: to ensure that the fracture pressure is not exceed, to give enough soak time after finishing gel injection and before re-injection of water in order to achieve adequate rigidity and to restart injection of water in slight increases of flow. It is also important inject the mixture with a growing polymer concentration, always that the injection conditions allows it. 


\section{Monitoring and Evaluation of the Pilot}

This stage commences with the implementation of the pilot itself. It is necessary to constantly verify that the chemical conditions of the design are met at the wellhead, verifying this element with the use of a permanent QA / QC represents added value of this methodology. Once the gel injection is finished the verification of the variables that determine the success or failure of the process should be carried out. The presence of the polymer in production wells is seen as a negative sign, since it would indicate production of the chemicals, which are expected to remain at the reservoir. The injection pressure after treatment and rates of water and oil production in the influenced wells are the key parameters to determine the results. A key point, though not always taken into account, is the construction of a base line base of water and oil production; without this base line the results cannot be evaluated.

\section{DISCUSSION}

The chemical option presented in this paper was used in a real application in the field, which included analysis of the Tello field, and, where it was identified that there was also the need to intervene three injection wells in which there were channeling problems (Tello-4, Tello-7, Tello-49). An example of the results obtained can be seen in Figure 4, in which the base curve for production of oil is detailed as well as its incremental curve. Another positive result, which is in line with the available literature (Wouterlood et al., 2002, Norman et al., 2006), is the reduction in water cut in production wells, which can also be seen in Figure 4.

From the production results obtained, using total costs and incremental production achieved, a financial analysis shows the economic benefits of the executed pilots. Only by implementing the steps that were mentioned in this paper was it possible to obtain both the results and the necessary measurements. In terms of present net value and investment efficiency resulting values are 7.2 MUSD and 3.58, respectively.

The methodology presented here to design and implement polymer gel treatments for controlling water injected channeling was used in three injector wells, obtaining positive financial results in any case. World-

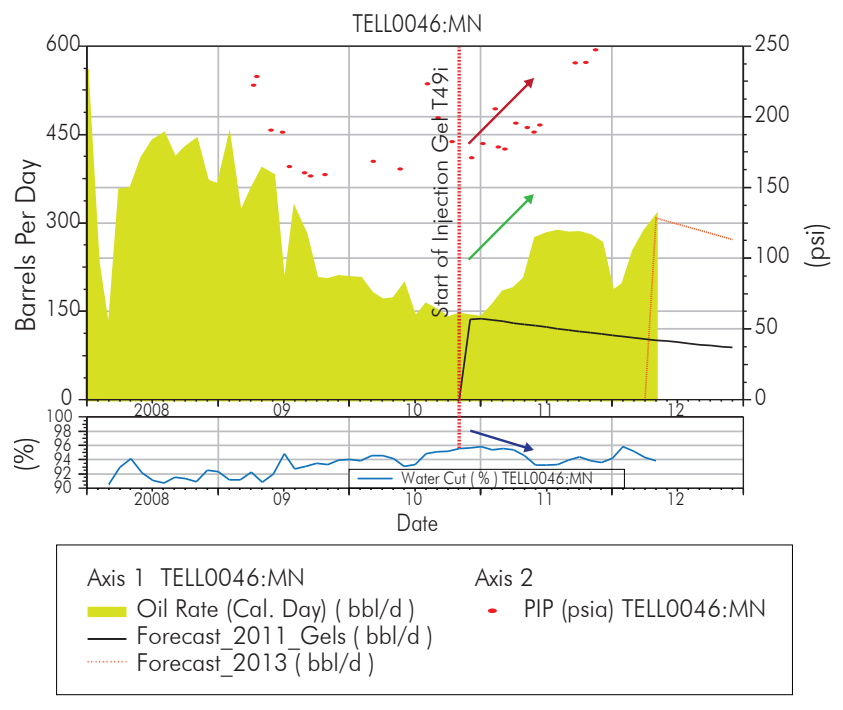

Figure 4. Production results obtained in the producer Tello 46 well after treatment with the polymeric gel in the injector Tello 49.

wide the average of success of this technology ranges between 60 and $70 \%$ approximately; so, although three cases are few cases to conclude, it is possible to say that the development presented here improves the average of success. It is also important to remark the impact that could be obtained by making of this technology a common practice, not only by the positive financial results already presented here, but for the environmental benefits in reducing the water production rate.

\section{CONCLUSIONS}

- The polymer gels technology implemented, as a thief zone control, is an option that can be used as a supplement to optimize water injection processes.

- The methodology designed reduces the inherent risk of applying chemical conformance treatments, and increases the chances of achieving positive results in optimization of water injection.

- The study carried out not only allowed for the development of the first pilot in relation to Ecopetrol S.A. technology, but it also favored the incorporation of laboratory protocols and engineering analyzes required to make technology viable and present it as another option for reservoir optimization. 


\section{ACKNOWLEDGMENTS}

The authors express their gratitude to Ecopetrol $S . A$. for given their consent in relation to the publication of these results and for their generous support throughout the project. Special thanks to the Superintendencia de Yacimientos (SYA), Superintendencia Huila-Tolima (SOH) and the Instituto Colombiano del Petróleo (ICP).

An additional acknowledgment to Tiorco L.L.C. for their accompaniment, monitoring and support in the design and implementation of this work.

\section{REFERENCES}

Borling, D., Chan, K., Hughes, T. \& Sydansk, R. (1994). Pushing out the oil with conformance control. Oilfield Review, 6(2), 44-51.

Delgadillo, C. (2010). Evaluación de la viabilidad técnica de implementación de procesos de inyección de agua. Tesis de maestría Fac. Ingeniería Fisicoquímicas, Universidad Industrial de Santander, Bucaramanga, Colombia, 178pp.

Gall, J. (1973). Subterranean formation permeability correction. U.S.A Patent 3, 762,476. Bartlesville, Oklahoma. Int. CL.: E21b 33/138, E21b 43/22.

Gall, J. (1976). Partially crosslinked polymer used in correcting subterranean formation permeability. U.S.A Patent 3,981,363. Bartlesville, Oklahoma. Int. CL.: E21b 33/138, E21b 43/22.

Gall, J. (1977). Controlled well plugging with dilute polymer solutions. U.S.A Patent 4,018,286. Bartlesville, Oklahoma. Int. CL.: E21b 33/138.

Ibarra, J. (2010). Evaluación de la implementación de geles mediante simulación numérica. Tesis de pregrado Fac. Ingeniería fisicoquímicas, Universidad Industrial de Santander, Bucaramanga, Colombia, 160pp.

Klaveness, T. \& Ruoff, P. (1994). Kinetics of the cross-linking of polyacrylamide with $\operatorname{Cr}(\mathrm{III})$. Analysis of possible mechanisms. J. Phys. Chem, 98(40), 10119-10123.
Klaveness, T., Ruoff, P. \& Kolnes, J. (1995). Kinetics of the cross-linking of polyacrylamide with $\mathrm{Cr}$ (III). Rheological measurements of the gelation. J. Phys. Chem. 99(20), 8255-8259.

Norman, C., Turner, B., Romero, J., Centeno, G. \& Muruaga, E. (2006). A review of over 100 polymer gel injection well conformance treatments in Argentina and Venezuela: design, field implementation and evaluation, Paper SPE 101781. First International Oil Conference and Exhibition, Cancún, Mexico.

Sydansk, R. \& Argabright, P. (1987). Conformance improvement in a subterranean hydrocarbon-bearing formation using a polymer gel. U.S.A. Patent 4,683,949. Findlay, Ohio. Int. CL.: E21b 33/138.

Sydansk, R. \& Romero-Zerón, L. (2011). Reservoir conformance improvement. Richardson: SPE

Wouterlood, C., Falcigno, E. \& Norman, C. (2002). Metodología y resultados de proyectos de inyección de geles para incrementar la recuperación en un reservorio heterogéneo y multicapa de la cuenca Neuquina de Argentina. INGEPET - EXPL-3-CW-04. Lima, Perú.

\section{AUTHORS}

\section{Gustavo-Adolfo Maya-Toro.}

Affiliation: Ecopetrol S.A. - Instituto Colombiano del Petróleo (ICP). Ing. Petróleos, Universidad Nacional de Colombia. Esp. Gerencia, Universidad Pontificia Bolivariana. e-mail: gustavo.maya@ecopetrol.com.co

Rubén-Hernán Castro-García.

Affiliation: Ecopetrol S.A. - Superintendencia de Yacimientos. Ing. Petróleos, Universidad América.

M. Sc. en Ing. Hidrocarburos, Universidad Industrial de Santander. e-mail: rubenHe.castro@ecopetrol.com.co

\section{Zarith del Pilar Pachón-Contreras.}

Affiliation: Ecopetrol S.A. - Instituto Colombiano del Petróleo (ICP). Química, M. Sc. en Química, Universidad Industrial de Santander. e-mail: zarith.pachon@ecopetrol.com.co

\section{Jose-Francisco Zapata-Arango.}

Affiliation: Ecopetrol S.A. - Superintendencia de Yacimientos. Ing. Químico, Universidad Industrial de Santander. M. Sc. in Petroleum Engineering, Texas A\&M University. e-mail: jose.zapata@ecopetrol.com.co 